\title{
Food loss assessment in micro, small and medium-sized agro- industrial enterprises
}

\section{Evaluación de pérdida de alimentos en una micro, pequeña y mediana empresa agroindustrial}

Rooel Campos-Rodríguez ${ }^{1}$, Laura Brenes-Peralta², Arlyn Garcia-Salas ${ }^{3}$, María Fernanda Jiménez-Morales ${ }^{4}$

Campos-Rodríguez, R; Brenes-Peralta, L; Garcia-Salas, A; Jiménez-Morales, M.F. Food loss assessment in micro, small and medium-sized agro-industrial enterprises. Tecnología en Marcha. Vol. 34-3 Julio-Setiembre 2021. Pág 143-155.

doi) https://doi.org/10.18845/tm.v34i3.5122

1 Doctor in Natural Sciences for Development. Professor and Researcher of the Agribusiness School. Coordinator of the Agroforestry Academic Area. Instituto Tecnológico de Costa Rica. Costa Rica. Email address: rocampos@tec.ac.cr (iD) https://orcid.org/0000-0003-4460-2313

2 Agricultural Administrative Engineer and Master in Environmental Management. Research Professor. Agribusiness School. Instituto Tecnológico de Costa Rica. Costa Rica. Email address: labrenes@tec.ac.cr (iD) https://orcid.org/0000-0002-5169-9961

3 Master in Natural Resources Management and Production Technologies. Instituto Tecnológico de Costa Rica. Costa Rica. Email address: arggsa@gmail.com

4 Agricultural-Administrative Engineer and Master in Modern Manufacturing Systems. Research Professor. Agribusiness School. Instituto Tecnológico de Costa Rica. Costa Rica. Email address: maria.jimenez@tec.ac.cr 


\title{
Keywords
}

Agro-industry; critical points; food loss; waste.

\begin{abstract}
This research emerges from a growing concern to face the problem owing to food loss (FL), with the purpose to evaluate processes in agro-industrial product elaboration, focusing on the determination of food loss critical points (FLCP) to promote their further reduction. The research was carried out in a Costa Rican MSME (micro, small and medium-sized enterprise), dedicated to the processing of tropical fruits. The FL assessment proposed methodology enabled the establishment of a food loss valorization team (FLVT) for a multidisciplinary approach throughout the study, as well as a flowchart construction for the selected process (soursop pulping) and the identification and quantification of losses. The assessment of the food loss points (FLP) was performed using a matrix and a criticality index based on severity and probability of occurrence; which led to the identification of the critical points. As a result, four FLCP were detected; regarding the raw materials input, the pulping operation and the transference of processed pulps into containers. The case study shows that the applied methodology allows to determine FLCP in an MSME such as the studied, as a first action to identify and reduce food loss, improve efficiency and consider further waste management strategies.
\end{abstract}

\section{Palabras clave}

Agroindustria; puntos críticos; pérdida de alimentos; residuos.

\section{Resumen}

Esta investigación surge en un contexto de creciente preocupación por enfrentar la problemática de la pérdida de alimentos (PA), con el objetivo de evaluar los procesos de elaboración de productos agroindustriales centrándose en la determinación de puntos críticos de pérdida de alimentos (PCPA) para promover su reducción.

La investigación se realizó en una MiPyme (micro, pequeña y mediana empresa) costarricense, dedicada al procesamiento de frutas tropicales. La metodología propuesta para la evaluación de PA permitió la conformación de un Equipo de Valorización de Pérdida de Alimentos (EVPA) para un enfoque multidisciplinario a lo largo del estudio, así como la construcción de un diagrama de flujo para el proceso seleccionado (pulpa de guanábana) y la identificación y cuantificación de las pérdidas. La evaluación de los puntos de pérdida de alimentos (PPA) se realizó utilizando una matriz y un índice de criticidad basados en la severidad y probabilidad de ocurrencia; lo que condujo a la identificación de los puntos críticos. Como resultado, se detectaron cuatro PCPA; relacionados con el ingreso de materias primas, la operación despulpado y la transferencia de las pulpas procesadas a los contenedores. El estudio de caso muestra que la metodología aplicada permite determinar los PCPA en una MiPyme como la estudiada; como una primer medida para identificar y reducir la pérdida de alimentos, mejorar la eficiencia y valorar nuevas estrategias de gestión de alimentos. 


\section{Introduction}

Sustainable Development Goals (SDG) seek to raise awareness and improve the people's habits towards sustainable production and consumption [1]. Therefore, the regard of food losses and waste (FLW) can have a positive impact on SDG 12, specifically on target 12.3, which seeks to reduce FLW in production chains [2]. At international and local levels, efforts have been brewing to identify, quantify, reduce and prevent FLW. In 2015, the UN Member States [3] approved the goal of reducing, by 2030, food losses in production and distribution chains, for which a Global Food Loss Index must be foreseen [1], even when methodological considerations for quantification are still in development.

The Food and Agriculture Organization of the United Nations -FAO, estimated that one third of the world's food production is wasted or lost along the food supply chain. Food loss (FL) refers to the decrease in the available mass of food for human consumption in the production, postharvest, storage and transport phases [2].

Globally, the economic cost of losses amounts 1 billion dollars (USD) per year; about 700 billion dollars (USD) must be added for environmental costs and another 900 billion dollars (USD) of social costs, for a total of 2.6 trillion dollars (USD) per year [2]. Consequently, there is a growing interest to work on FL, due to the economic implications from a cost-benefit perspective.

In addition to $\mathrm{FL}$ in production processes, and the given complex links between producers, suppliers, and consumers [4], food security, also challenged by FL, is becoming transcendental due to climate change [5] and to changes in production factors. If the current pattern of food use is maintained, coupled with population growth, by 2050 there should be a $60 \%$ increase in world agricultural production to meet the demand [6], [7].

Similarly, possible benefits for the environment could be present as well if FL is adressed [8], since more efficient processes will not only have economic and food security implications, [9], but will entail a better use of resources. The lost food is linked to inappropriate use of energy, water and greenhouse gas emissions generated by operations during their production [10].

FLW can occur in almost any link in the production chain, from harvesting, processing and final consumption, for various reasons from bad planning and expiration of food-products, to human failures or equipment in poor condition in the processing phase [11]. FL, in particular, are identified in the earlier stages of the food supply chains, caused by technical, management, storage and processing constraints, inappropriate equipment and packaging problems, among others [2]. Accordingly, it is essential to guarantee the efficiency of agro-industrial processes and to have sufficient information about factors that can lead to waste generation as result of FL at this level, in order to promote science-based interventions.

Agro-industrial-type processing is a common alternative to link primary production with consumers through processing and value adding techniques and, reducing $\mathrm{FL}$ in this section of the food supply chain can represent an opportunity for management of surpluses and preventing or reducing waste generation whenever possible through proper administration of the operations. [12].

In fact, there are empirical studies that show that a reduction in discarded waste can lead to significant savings for companies [12]. This idea introduces the opportunity of making the business case for reducing FLW, arguing it can generate a triple win: (1) it can save money for farmers, companies and households; (2) it can help feed more people; and (3) it can alleviate pressure on water, land and climate [13]. The analysis of historical data shows there is a robust business case for countries, cities and companies to reduce FLW [13]. An example of the adoption of this idea is given by the United Kingdom (UK), where a nationwide initiative was launched in 2007 to reduce household food waste, and by 2012 a reduction of $21 \%$ of FLW 
was achieved compared to the country's baseline. The ratio of purely financial cost/benefit attributable to the UK initiative was over 250:1, meaning a substantial return on £1 investment resulted in savings of £250. Similarly, Garrone et al. [12] emphasize that cities can also achieve high returns on their investment in FLW reduction. Finally, the return on investment in FLW reduction for companies can also be significant.

In countries with developing economies such as Costa Rica and those in the Latin American and Caribbean Region, there are still imprecise estimates on FL and its effects. However, the processing stage is suggested to entail 6\% of FL [14], given that deficiencies in the used technologies following the post-harvest and transformation processes, are often recognized as FL hotspots.

The Costa Rican agri-food sector is not exempt from the aforementioned problems, in addition to its need to compliance with the Integral Waste Management Law no.8839 [16], which highlights the need to create comprehensive and dynamic solutions including first the prevention of waste generation, and following disciplines linked to circular economy and hierarchy of waste management to address this issue [17].

Subject to this, the analysis of critical points can work as a methodology for addressing waste in the production process. This system known as HACCP (Hazard Analysis and Critical Control Points) applied for Food Safety management, could be emphasized and adapted in other possible points that would be generating problems throughout the production process [15]. This would translate into considering the flowchart analysis of the agro-industrial process, identifying food loss critical points (FLCP) by obtaining a criticality index, which depends on the severity and probability of occurrence of the losses found in the evaluated processes, and once the significance is determined, proper interventions can begin to be considered.

Therefore, the objective of this research was to propose an adapted methodology based on HACCP and apply it in a case study of a small fruit processing agroindustry, to allow in a future, a more effective and environmentally friendly production.

\section{Methodology}

\section{Process Flow Diagrams}

The research was carried out in Cartago, Costa Rica, in a small company dedicated to the processing of fruits to produce pulps and beverages. A working group called the Food Loss Valorization Team (FLVT) was formed by academics in FL and biowaste valorization, and company representatives dedicated to quality control, management, and production.

The FLVT was responsible for prioritizing the production processes to be assessed, according to criteria such as cost, sales volume, production, profit margin and product leadership in the market. In this sense, the team selected to study the pulp processing of soursop (a tropical fruit known as guanabana in Costa Rica, Annona muricate). The FLVT team also met to review existing documents in the company and consider the criteria of the members and personnel to construct the production flowchart from the reception of the raw materials to the processed product storage. From the aforementioned, process flows were schematized, incorporating the unit operations sequence, process conditions, ingredients and additives, reprocessing, final products, intermediate products, by-products and discards. The definition of process flows, observations and unstructured communications within the FLVT with the personnel, allowed the pre- identification of potential food loss points (FLP), which allowed to later move towards the next phase of FL quantification and FLCP determination. 
Due to resources and time availability, the team defined to conduct a minimum of five repetitions to collect the necessary data using collection tools designed for the study and aided by Microsoft Excel ${ }^{\circledR}$ spreadsheets. The FLVT planned for the data collection chronogram, executed the FL measurement, analyzed the information and validated the results through in situ verifications.

\section{Quantification of FL}

Based on five observations of production batches, and the unit operations described in the schematized flow charts, the researchers measured the amount of inputs and outputs, as well as the discards, spilled mass and waste on each unit operation (when possible) where FLP were identified. This allowed to conduct a mass balance for each considered unit operation and calculate the FL along the process flow, both in absolute $(\mathrm{kg})$ and relative (\%) units.

\section{Evaluation of food losses and definition of food loss critical points (FLCP)}

The hazard assessment matrices already used by other authors [15 and 18] in food safety were taken as a base tool, adjusting the definition of parameters to assess critical control points with respect to FL. This assessment considered the severity $(\mathrm{S})$ and the probability of occurrence $(\mathrm{O})$ of FL at each waste generation point, using a rating scale from 1 to 5 (Table 1), which allowed the calculation of a criticality index defined by the equation 1. Considering that $F L$ in the processing stage of food supply chains in Latin America and the Caribbean is estimated at 6\% [14], and these estimates are intended to provide a baseline for optimizing production yields, the severity (S) scale in this case study used that as the maximum value of $F L$, and then categories were calculated. The probability of occurrence $(\mathrm{O})$ scale, undertook frequency descriptors, such as rarely, occasionally, often, usually and always, based on the amount of times a FL was observed during the five repetitions.

$$
C I=S \times O
$$

Where:

Cl: Criticality Index

S: Severity

O: Probability of Occurrence

After applying equation 1, the significance of the FL generation was evaluated using the values in table 2 as a reference. The FL points where the losses have a medium or high significance are considered FLCP.

The obtained significance results were included in an evaluation matrix with the unit operation, the identified FL points (FLP), the severity rating $(\mathrm{S})$, the probability of occurrence rating $(\mathrm{O})$, the calculated the criticality index $(\mathrm{Cl})$ and the significance of such FLP. 
Table 1. Parameters and values in the assessment of FL.

\begin{tabular}{|c|c|c|c|}
\hline \multicolumn{2}{|l|}{ Severity } & \multicolumn{2}{|l|}{ Probability of Occurrence } \\
\hline Criteria & Rating value & Criteria & Rating value \\
\hline $\begin{array}{l}\text { Scarce: Weight of the } \mathrm{FL}<1.2 \text { of the } \\
\text { weight of the raw material input within the } \\
\text { evaluated operation, if generated }\end{array}$ & 1 & $\begin{array}{l}\text { Rarely: The FL was presented within } \\
\text { the evaluated operation in } 1 \text { of the } 5 \\
\text { repetitions }\end{array}$ & 1 \\
\hline $\begin{array}{l}\text { Mild: } 1.2 \leq \text { Weight of } F L<2.4 \text { of the } \\
\text { weight of the raw material input within the } \\
\text { evaluated operation, if generated }\end{array}$ & 2 & $\begin{array}{c}\text { Occasionally: The FL was presented } \\
\text { within the evaluated operation in } 2 \text { of } \\
\text { the } 5 \text { repetitions }\end{array}$ & 2 \\
\hline $\begin{array}{l}\text { Moderate: } 2.4 \leq \text { Weight of the } F L<3.6 \text { of } \\
\text { the weight of the raw material input within } \\
\text { the evaluated operation, if generated }\end{array}$ & 3 & $\begin{array}{c}\text { Often: The FL was presented within } \\
\text { the evaluated operation in } 3 \text { of the } 5 \\
\text { repetitions }\end{array}$ & 3 \\
\hline $\begin{array}{l}\text { High: } 3.6 \leq \text { Weight of the } \mathrm{FL}<4.8 \text { of the } \\
\text { weight of the raw material input within the } \\
\text { evaluated operation, if generated }\end{array}$ & 4 & $\begin{array}{c}\text { Frequently: The LF was presented } \\
\text { the evaluated operation in } 4 \text { of the } 5 \\
\text { repetitions }\end{array}$ & 4 \\
\hline $\begin{array}{l}\text { Very high: Weight of the } F L \geq 4.8 \text { of the } \\
\text { weight of the raw material input within the } \\
\text { evaluated operation, if generated } d\end{array}$ & 5 & $\begin{array}{l}\text { Always: The LF was presented within } \\
\text { the evaluated operation in } 5 \text { of the } 5 \\
\text { repetitions }\end{array}$ & 5 \\
\hline
\end{tabular}

Source: Author creation from Cartín et al. [15]

Table 2. Significance of losses according to the criticality index.

\begin{tabular}{|c|c|}
\hline Significance & Significance Value \\
\hline Low & $<10$ \\
\hline Medium & $10<\mathrm{X}<15$ \\
\hline High & $>15$ \\
\hline
\end{tabular}

\section{Results and discussion}

\section{Process Flow Diagrams}

According to the selection made by FLVT and observations, figure 1 presents the flow chart of the soursop pulp process.

Through the individual review of the unit operations within the overall soursop process, six FLP were identified, such as the raw material input, pulping, resting, pasteurization, sieving and packaging and sealing. 


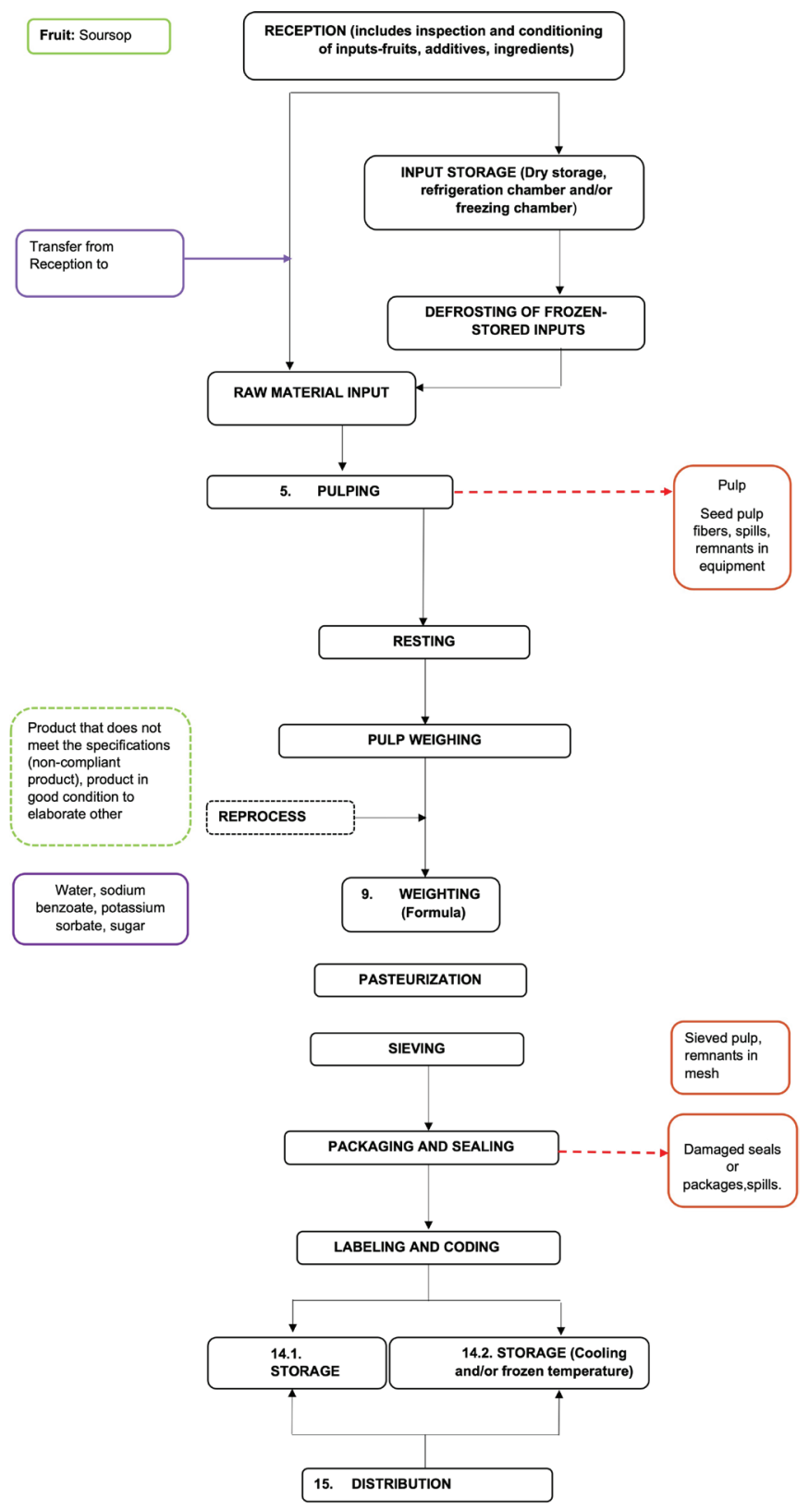

Figure.1. Flowchart processing for soursop pulp.

FL quantification in identified FLP in the soursop pulp production process

The six-unit operations where FLP were identified occur throughout the production process as indicated by the FLVT and plant personnel. Therefore, the mean FL is presented in table 3, as a result of the FL quantification in the five repetitions from this study. 
Table 3. Quantification of the FL in the soursop concentrate production process.

\begin{tabular}{|c|c|c|c|}
\hline \multirow{2}{*}{ Unit operation } & \multirow{2}{*}{ Food loss point } & \multicolumn{2}{|c|}{ FL average } \\
\hline & & $(\mathrm{kg})$ & $(\%)$ \\
\hline \multirow{2}{*}{$\begin{array}{l}\text { Raw material } \\
\text { input }\end{array}$} & Spill of soursop juice when package is cut to place in equipment & 2,05 & 1,84 \\
\hline & Soursop remnants inside the packages & 3,37 & 3,08 \\
\hline \multirow{6}{*}{ Pulping } & Soursop juice leaks when opening pulping equipment gate & 1,58 & 1,55 \\
\hline & Pulp splashing at the pulping equipment outlet & 0,35 & 0,32 \\
\hline & Pulp drop on the floor during container transference & 1,03 & 0,97 \\
\hline & Overflow of pulp deposited in the type1-containers & 0,83 & 0,80 \\
\hline & Pulp adhered to the type1-container walls & 1,17 & 1,17 \\
\hline & Pulp spills in the transfer from the type1-containers to bins & 1,38 & 1,42 \\
\hline \multirow{2}{*}{ Resting } & Pulp attached to the utensils used to from bins to type2-container & 0,43 & 0,47 \\
\hline & Spills in the transfer from bins to type2-container & 0,87 & 1,02 \\
\hline \multirow{3}{*}{ Pasteurization } & Pulp spilled in the transfers to the pasteurization equipment & 0,55 & 0,50 \\
\hline & Concentrate overflow from one of the pasteurization equipment & 10,42 & 0,97 \\
\hline & $\begin{array}{l}\text { Leakage of concentrate when decoupling the suction equipment to } \\
\text { move it from one pasteurization equipment to the other }\end{array}$ & 4,08 & 0,39 \\
\hline Sieving & Residue retained in the sieve mesh & 4,92 & 0,48 \\
\hline \multirow{5}{*}{$\begin{array}{l}\text { Packaging and } \\
\text { sealing }\end{array}$} & Spill of the product into a holding tank prior to packaging & 0,73 & 0,07 \\
\hline & $\begin{array}{c}\text { Disposal of product deposited in the tray when the process is } \\
\text { finished }\end{array}$ & 1,05 & 0,11 \\
\hline & Product overflow during automatic packaging & 1,00 & 0,09 \\
\hline & Product overflow during manual packaging & 0,65 & 0,06 \\
\hline & Spill during the collection of samples of the processed product & 0,07 & 0,01 \\
\hline
\end{tabular}

\section{Evaluation of food loss points (FL)}

Considering the obtained data from table 3 , as well as its assessment regarding the parameters presented in table 1 for S and O, the FLVT applied equation 1 to calculate the $\mathrm{Cl}$. The obtained results were categorized according to table 2. A summary of these data is presented in table 4, where it is seen that, from the six-unit operations where FLP were identified, the Raw Materials Input and the Pulping unit processes are the ones that present four FLCP, since they ranked as medium and high criticality rates. 
Table 4. Evaluation of FL points in the production process of soursop concentrate.

\begin{tabular}{|c|c|c|c|c|c|}
\hline Unit operation & Food loss description & Severity (S) & $\begin{array}{l}\text { Probability of } \\
\text { occurence }(\mathrm{O})\end{array}$ & $\begin{array}{l}\text { Criticality } \\
\text { index (Cl) }\end{array}$ & Significance \\
\hline \multirow{2}{*}{$\begin{array}{l}\text { Raw material } \\
\text { input }\end{array}$} & $\begin{array}{l}\text { Spill of soursop juice when package } \\
\text { is cut to place in equipment }\end{array}$ & 2 & 5 & 10 & Medium \\
\hline & $\begin{array}{l}\text { Soursop remnants inside the } \\
\text { packages }\end{array}$ & 3 & 5 & 15 & High \\
\hline \multirow{6}{*}{ Pulping } & $\begin{array}{l}\text { Soursop juice leaks when opening } \\
\text { pulping equipment gate }\end{array}$ & 2 & 5 & 10 & Medium \\
\hline & $\begin{array}{l}\text { Pulp splashing at the pulping } \\
\text { equipment outlet }\end{array}$ & 1 & 5 & 5 & Low \\
\hline & $\begin{array}{l}\text { Pulp drop on the floor during } \\
\text { container transference }\end{array}$ & 1 & 5 & 5 & Low \\
\hline & $\begin{array}{l}\text { Overflow of pulp deposited in the } \\
\text { type1-containers }\end{array}$ & 1 & 5 & 5 & Low \\
\hline & $\begin{array}{l}\text { Pulp adhered to the type1-container } \\
\text { walls }\end{array}$ & 1 & 5 & 5 & Low \\
\hline & $\begin{array}{l}\text { Pulp spills in the transfer from the } \\
\text { type1-containers to bins }\end{array}$ & 2 & 5 & 10 & Medium \\
\hline \multirow{2}{*}{ Resting } & $\begin{array}{l}\text { Pulp attached to the utensils used to } \\
\text { from bins to type2-container }\end{array}$ & 1 & 5 & 5 & Low \\
\hline & $\begin{array}{l}\text { Spills in the transfer from bins to } \\
\text { type2-container }\end{array}$ & 1 & 5 & 5 & Low \\
\hline \multirow{3}{*}{ Pasteurization } & $\begin{array}{l}\text { Pulp spilled in the transfers to the } \\
\text { pasteurization equipment }\end{array}$ & 1 & 3 & 3 & Low \\
\hline & $\begin{array}{c}\text { Concentrate overflow from one of the } \\
\text { pasteurization equipment }\end{array}$ & 1 & 5 & 5 & Low \\
\hline & $\begin{array}{c}\text { Leakage of concentrate when } \\
\text { decoupling the suction equipment } \\
\text { to move it from one pasteurization } \\
\text { equipment to the other }\end{array}$ & 1 & 5 & 5 & Low \\
\hline Sieving & Residue retained in the sieve mesh & 1 & 5 & 5 & Low \\
\hline \multirow{5}{*}{$\begin{array}{l}\text { Packaging and } \\
\text { sealing }\end{array}$} & $\begin{array}{c}\text { Spill of the product into a holding tank } \\
\text { prior to packaging }\end{array}$ & 1 & 3 & 3 & Low \\
\hline & $\begin{array}{l}\text { Disposal of product deposited in the } \\
\text { tray when the process is finished }\end{array}$ & 1 & 5 & 5 & Low \\
\hline & $\begin{array}{c}\text { Product overflow during automatic } \\
\text { packaging }\end{array}$ & 1 & 3 & 3 & Low \\
\hline & $\begin{array}{l}\text { Product overflow during manual } \\
\text { packaging }\end{array}$ & 1 & 4 & 4 & Low \\
\hline & $\begin{array}{c}\text { Spill during the collection of samples } \\
\text { of the processed product }\end{array}$ & 1 & 4 & 4 & Low \\
\hline
\end{tabular}


Brainstorming within the FLVT and personnel considered that this FLP are mainly due to human error, deficiencies in the packaging material or aspects related to preventive maintenance and characteristics of the equipment. The nature of the processes and the design of the equipment were factors that hinder of a standard to measure inputs and outputs in the different unit operations, including the direct measurement of losses, so it was necessary to proceed by weighing all the inputs, outputs and waste that the process would allowed, and the joint processing of such information allowed estimating the generation at the FLP identified. In other cases, direct mass measurements of the waste can be executed, if the process allows for it. It is also observed, that one operation unit can have two or more FLP, and such situation required that each of these points were to be quantified and assessed separately, since the origin of $F L$ generation is different.

According to the information in tables 3 and 4, most average losses in FLP are below 1,2\% of the weight of the raw material used in each production batch; however, certain unit operations presented losses above that value due to manual transfer of inputs into equipment, or from equipment to containers, which led to spills, leaks, pulp that remains adhered to packaging or walls of the bins and equipment during pulping, or juice that leaked when the hopper door of the pulping machine was opened or presented excessive movement or vibration.

The raw material input operation entailed two FLCP. In this operation, the collaborator extracted the raw soursop contained in plastic bags, cut them at the top and deposited the soursop in the hopper of the hammer mill for the pulping operation. Part of the content of the bags was the soursop juice, which spilled when the bags were opened, causing the loss of raw material. In addition, small quantities of soursop remained attached to these packages. The pulping operation also presented a FLCP when the equipment gate was opened, and juice leaks or splashes were detected. Finally, the fourth FLCP was observed at the end of the pulping operation, when the product could spill while being transferred due to human error or overloading of the container. It is relevant to indicate that most of the severity parameter (S) was qualified in 1, 2 or 3 values; however, the probability of occurrence was valued at 5 , due to the fact that it always occurred during this case study repetitions.

Observations and expert criteria of the FLVP regarding the soursop concentrate production process, also suggested that potential damages in the equipment could result in FL if not addressed in a timely manner. This is the case of the failures in the automatic filling nozzles of the containers and the pulping machine; however, this were not observed at the moment of the study.

In general, the observations made on the production processes showed opportunities for improvement in relation to the weighing of raw materials and inputs of each operation, as this could be both a diagnostic and a control measure to achieve the FL reduction target. The quantification will allow for strategic interventions, the planning for FW valorization alternatives and validation of the interventions after a new application of the FLP evaluation.

In summary, the case study allowed to apply this proposed adapted FLCP methodology, as observed in figure 2. 


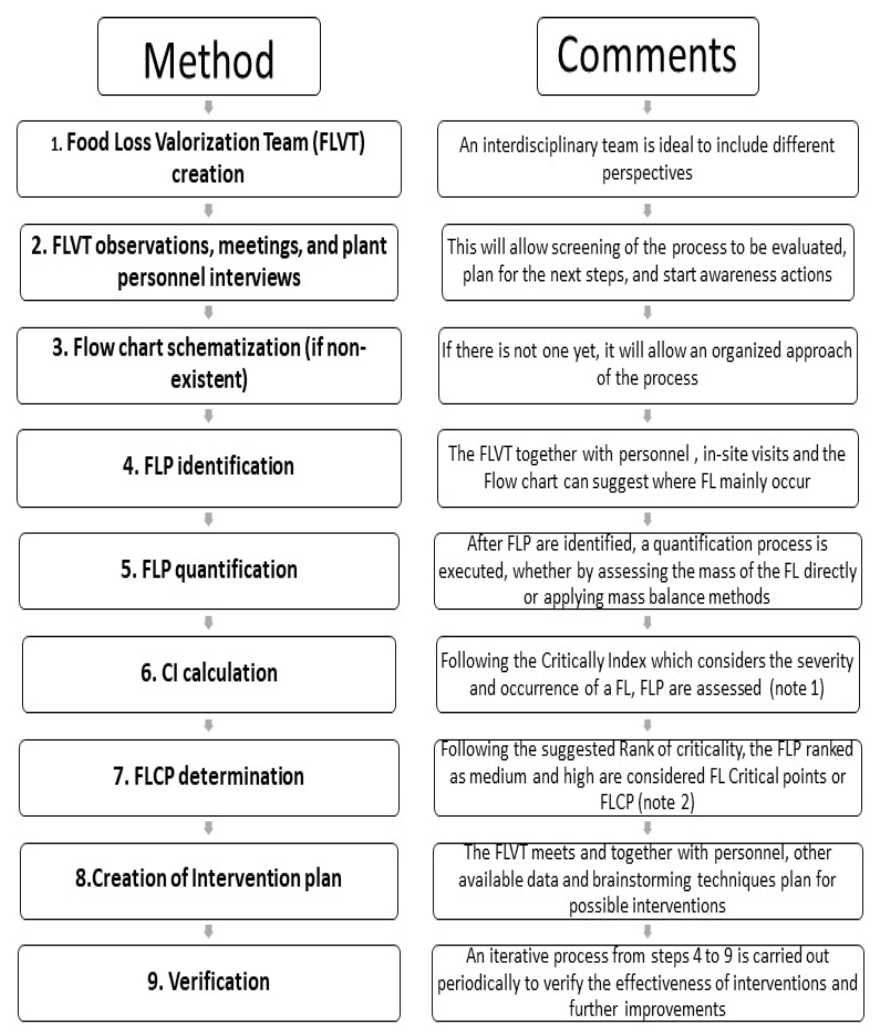

Figure 2. FLCP proposed methodology for FL assessment in MSME agro-industries

Note 1: The severity (S) can be modified according to the company's goals and acceptable thresholds, if not the estimate of $6 \%$ based on available literature for the FL case in LatinAmerica and the Caribbean is suggested. The occurrence $(O)$ can also be modified depending on the amount of possible repetitions, suggested at a minimum of three.

Note 2: the significance is calculated after applying equation 1 of this document and the significance value in table 2 of this document.

\section{Conclusions}

The quantification of food losses at the agro-industry processing level is a topic for further study to establish practical guidelines for data collection and assessment, such as procedures and use of technological tools, which must be based on rigorous knowledge of the architecture of production processes.

This investigation demonstrates that it is possible to adapt an existing methodology, used from the food safety approach, to determine in a simple way the losses of food in an agro-industry process, through the evidence of the FLCP. Then, they can evaluate the criticality of losses within the production process.

The applied tool to the studied agro-industrial company, shows few losses suggesting the efficiency of the process, but still opportunities for improvement are detected. It also demonstrates that its application is simple and practical in this context; it allows to have more control over the productive process and aids to determine critical points of FL which must be regarded to avoid its increase. It also enables evidence-based potential interventions. Once they are planned, this tool could be the start for reducing the potential negative impact on the environment triggered 
by FLW or unutilized by-products that are not treated properly, or simply sent to final disposal. These latter could be incorporated into other productive processes that would generate added value, and would contribute significantly to the bioeconomy from a circular economy approach.

\section{Acknowledgements}

The authors would like to recognize the support from students who contributed to different stages of this study, Fiorella Ramírez, Jonathan Castro, Mariajosé Esquivel and Arlyn García. We would also like to give a special thank you to Esteban Rojas y Federico Vargas \& team, for their willingness to participate in the study, while we recognize their commitment for a truly sustainable approach in their agro-industrial activity.

\section{References}

[1] UNDP (United Nations Development Program). "Agenda de desarrollo post-2015". In: https://www.cr.undp.org/ content/costarica/es/home/post-2015/sdg-overview/ , 2019.

[2] FAO (Food and Agriculture Organization of the United Nations). "The State of Food and Agriculture 2019. Moving forward on food loss and waste reduction". Rome. Licence: CC BY-NC-SA 3.0 IGO, 2019.

[3] UN (United Nations). "Transforming Our World: The 2030 Agenda for Sustainable Development. Obtenido de United Nations". In: https://sustainabledevelopment.un.org/post2015/transformingourworld, 2015.

[4] J. Gustavsson, J.C. Cederberg \& U. Sonesson. "Global Food Losses and Food Waste: Extent, Causes and Prevention", Study Conducted for the International Congress Save Food At Interpack 2011, [16-17 May], Düsseldorf, Germany Food and Agriculture Organization of the United Nations, Rome, 2015.

[5] P.C. Nelson \& E.D. Young. "Enhancement in the Marmoset Inferior Colliculus: Neural Correlates of Perceptual "Pop-Out". In: E. Lopez-Poveda, A. Palmer, R. Meddis, Eds. The Neurophysiological Bases of Auditory Perception. Springer, New York, NY, 2010.

[6] FAO (Food and Agriculture Organization of the United Nations). "Costa Rica mantiene tendencia a la disminución del hambre y la desnutrición". Retrieved from: http://www.fao.org/costarica/noticias/detail-events/ en/c/463756/ . 2017.

[7] J. Aschemann, N. Raak, H. Rohm, C. Symmank \& S. Zahn. "Processing- and product-related causes for food waste and implications for the food supply chain". V 61. Waste Management, 2017, pp 461-472.

[8] B. Ellison, M.K. Muth \& E. Golan. "Opportunities and Challenges in Conducting Economic Research on Food Loss and Waste". Applied Economic Perspectives and Policy 42 (1), 2019, pp 1-19.

[9] C.E. Landry \& T.A. Smith. "Demand for household food waste". Applied Economic Perspectives and Policy 41 (1), 2019, pp 20-36.

[10] R. Lozano, E. Papargyropoulou, J. Steinberger, Z. Ujang \& N. Wright, N.. "The food waste hierarchy as a framework for the management of food surplus and food waste". V 76. Journal of Cleaner Production, 2014, pp 106-115.

[11] N. Wilson, R. Miao \& C. Weis. "Seeing is not believing: perceptions of date labels over food and attributes". Journal Food Products Marketing 24:5, 2018, pp 611-631.

[12] P. Garrone, M. Melacini, A. Perego \& S. Sert. "Reducing food waste in food manufacturing companies". V 137. Journal of Cleaner Production, 2016, pp 1076-1085.

[13] C. Hanson \& P. Mitchell. "The business case for reducing food loss and waste". A report on behalf of Champions 12.3. Retrieved from: http://www.wrap.org.uk/sites/files/wrap/Champions123_BusinessCase_Catering_0.pdf (accessed on 21 February, 2019).

[14] FAO (Food and Agriculture Organization of the United Nations). "Boletín Pérdidas y Desperdicio de Alimentos en América Latina y el Caribe". In: http://www.fao.org/3/a-i3942s.pdf . 2014.

[15] A. Cartín, A. Villarreal \& A. Morera. "Implementación del análisis de riesgo en la industria alimentaria mediante la metodología AMEF: enfoque práctico y conceptual". Rev. Med. Vet. (27), 2014, pp 133-148.

[16] Health Ministry. "Plan Nacional para la gestión integral de residuos 2016-2021". San José, Costa Rica, 2016. 
[17] G. Wehenpohl, \& C. Hernández. "Guía en la Elaboración de Planes Maestros para la Gestión Integral de los Residuos Sólidos Municipales”. México: Secretaría de Ecología del Gobierno del Estado de México, 2006, pp 78.

[18] R. Govender. "A hazard analysis methodology for the South African abattoir hygiene". British Food Journal, 116(12), 2014, pp 2026- 2047. 